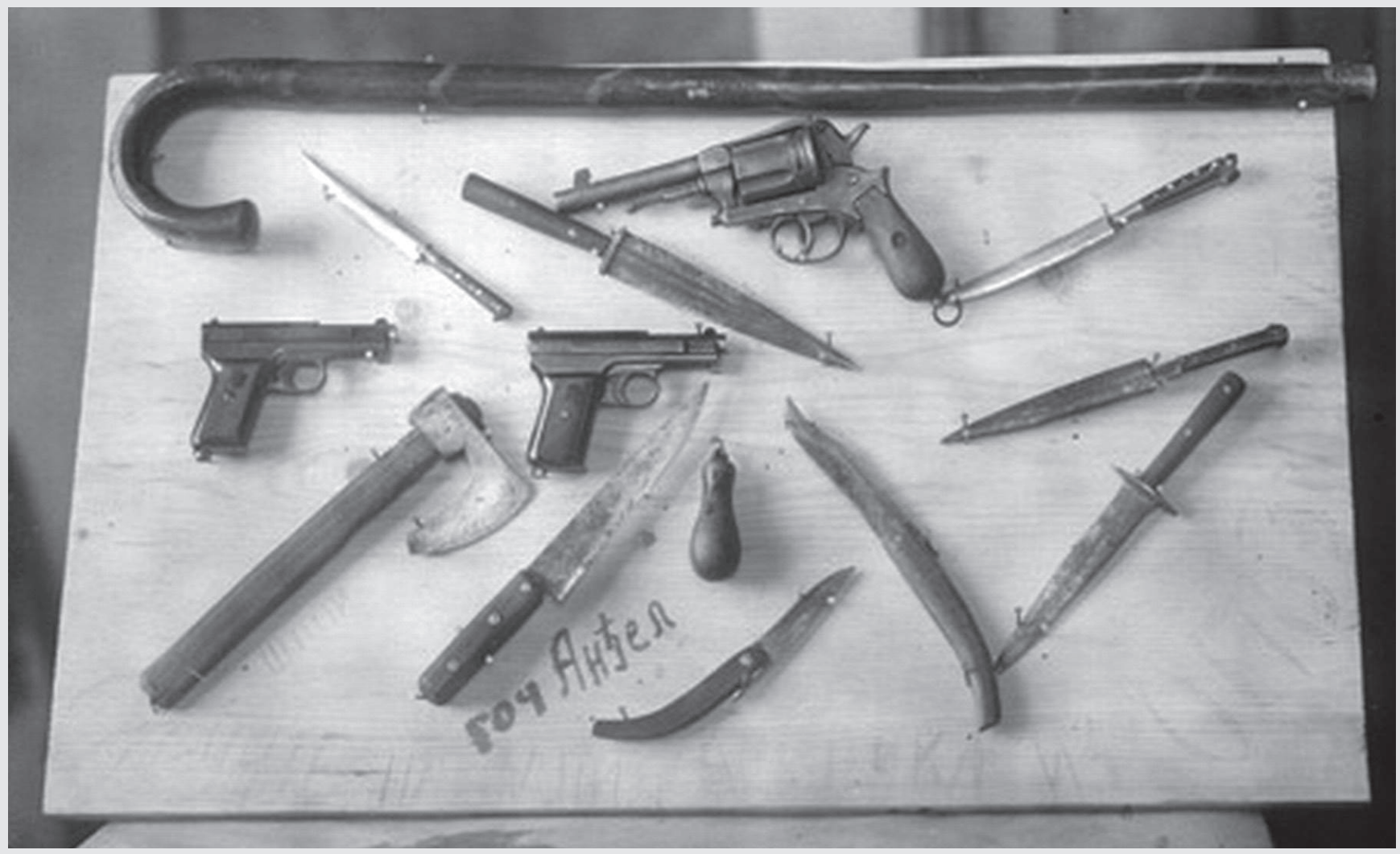

Uncivil Society: Weapons seized from the opposition during the municipal elections in Bujanovac,

December 6, 1936.

Source: Archiv Jugoslavije 


\section{Serbian Integral Nationalism, its \\ Opponents, and Mass Violence in \\ THE BALKANS I903-I945}

The article traces a line of continuity in Serbian nationalizing

tendencies from the palace coup in Belgrade 1903 through

to the defeat of Serbian nationalist forces in the Yugoslav

Civil War of 1941-1945. Due attention is paid to opponents

of these forces, in Austria-Hungary, and later amongst

Croats. The article uses Alan Kramer's concept of a 'dynamic

of destruction' to show how rivalries between these forces

repeatedly created the conditions for mass violence in the

South Slav lands.

\section{John Paul Newman}

links between the mass violence of 19121918 and 1941-1945 through an examination of Serbian integral nationalism and its opponents. In this article the term Serbian integral nationalism refers to the strain of Serbian nationalism that called for the integration of all Serb-populated lands into one national whole, generally without regard of existing political circumstances or the ethnic composition of the lands in question. This impulse was present throughout our period, it clashed with rival nationalisms and created what Alan Kramer was termed a 'dynamic of destruction', wherein violence and the destruction of non-national culture was 'both a by-product of combat and the consequence of a deliberate policy. ${ }^{2}$ Integral nationalists in Serbia frequently directed their efforts towards Kosovo and Macedonia, which were divided between vilayets (provinces) of the Ottoman Empire until 1912 and whose ethnic composition was mixed.

This article will argue that the supporters of this kind of nationalism strongly influenced the programme of the Yugoslav Army in the Fatherland (the Chetniks), pushing its leaders towards a policy of ethnic cleansing of non-Serbs as a means of creating an integral Serbian state on the territory they held. It will be shown that the Chetniks' ideology and their role in mass violence was determined in large part by supporters of the Serbian national project dating back to 1903 . Links will also be drawn between the opponents of this project: most notably Austria-Hungary, its supporters in the Croat lands during the First World War, and the Croatian fascist move-

1 From 1918-1929 the official name of the state was the Kingdom of Serbs, Croats, and Slovenes, thereafter it became the Kingdom of Yugoslavia. For the sake of brevity it will be referred to throughout this article as Yugoslavia.

2 Alan Kramer, Dynamic of Destruction: Culture and Mass Killing in the First World War (Oxford 2007) 1. 
ment, the Ustashe, during the Second World War. Like the Chetniks, the Ustashe were perpetrators of mass violence during the civil war in Yugoslavia during 1941-1945. AntiYugoslav Croats in exile formed the Ustasha Croatian Revolutionary Organization movement at the beginning of the 1930s, ostensibly as a response to the promulgation of the royal dictatorship in Yugoslavia the year before. The Ustashe partly was comprised ex-Habsburg officers of Croat descent and former Frankists, the latter a pro-Habsburg political faction strongly opposed to Serbian nationalism. This article will show that many of the founders of the Ustashe had also been associated with Austria-Hungary's violent attempts to 'denationalize' Serbia during the First World War.

\section{3: The 'Golden Age' Begins}

In 1903 a group of army officers deposed the Serbian King Aleksandar Obrenović, an event that significantly altered Serbia's trajectory in the twentieth century. Aleksandar had been on the throne in Serbia since 1889; during his reign many had become hostile to his autocratic style and many more were scandalized by his marriage to Draga Mašin, a widow and a woman 'with a past'. Officers in the Serbian Army felt that Aleksandar, as Supreme Commander of the Army, had brought their institution into disrepute. From 1902 onwards they conspired against him, and in May (O.S.) the following year they carried out a coup, breaking into the royal palace and murdering both Aleksandar and Queen Draga ${ }^{3}$ The coup was a bloody affair, both Aleksandar and Draga were thrown out of a palace window, after which conspirators on the ground below maimed their corpses with sabres. It caused outrage in diplomatic circles across Europe and had a number of important consequences in Serbia. Aleksandar was

For an account of the coup and its consequences: Wayne Vucinich, Serbia between East and West: The Events of 1903-1908 (Stanford 1954).

Neither the king nor the Radicals had been involved in the coup.

5 Two important monographs that make this point are Olga PopovićObradović Parlementarizam u Srbiji 1903-1914 (Belgrade 2008, 2 $2^{\text {nd }}$ edition), and Dubravka Stojanović, Srbija i demokratija:1903-1914: istorijska studija o "zlatnom dobu srpske demokratije" (Belgrade 2003). See also, Olga Popović-Obradovic, 'The Roots of Anti-Modern Political Culture in Serbia', Bosnia Report, 55-56 (January-July 2007), available at http://www.bosnia. org.uk/bosrep/report_format.cfm?articleid $=3183 \&$ reportid $=173$ [accessed 21 December 2010].

6 Vucnich, Serbia Between East and West, 131.132. replaced by Petar Karađorđević, heir of the rival Serbian dynasty, who returned from exile in Geneva to take the throne. Serbia became a constitutional monarchy, and the Serbian People's Radical Party formed the first postcoup government. The party would come to dominate the country's political scene until the outbreak of the First World War. ${ }^{4}$

A popular perception of Serbia from 1903 until 1914 is of a 'golden age' of functioning parliamentary democracy and constitutional rule. King Petar is often seen as an instinctively liberal king whose authority was curtailed by the constitution of 1903 , the People's Radical Party is cast as the midwife of a modern and democratic political system. Contrary to this perception, recent research has shown that the period from the coup until the outbreak of the First World War was characterized not only by democratic consolidation and institution-building but also by aggressive expansionism and hawkish foreign policy. For many in Serbia their kingdom in 1903 was surrounded by 'unredeemed' lands: to the south, the medieval Serbian lands of Kosovo and Macedonia, still part of the Ottoman Empire; to the west, Bosnia, with its large Serb population. The nationalists' dream was to integrate these lands into Serbia proper, so that the Serbs there could share in the golden age of political freedom and modernization. Nationalists particularly cherished the 'southern regions' of Kosovo and Macedonia, the sites of great importance to Serbia's historical and religious heritage. National awakeners of the nineteenth century had repeatedly emphasized the importance of these lands, the so-called 'classical south' of Serbia.

\section{War in the 'Classical South'}

There was, then, a will to redeem 'Serbian' lands; there was also a way. For years groups of Christian bandits had operated in the Ottoman Balkans. Known to the Ottomans as komitadji, they referred to themselves as četnici, a name derived from the Balkan word četa, meaning troop or (military) unit. In 1902 Serbian nationalists had organized a četnik 'executive committee' with branches in various towns across Serbia whose aim was to co-ordinate and strengthen the national character of banditry in the Ottoman Balkans. ${ }^{6}$ 


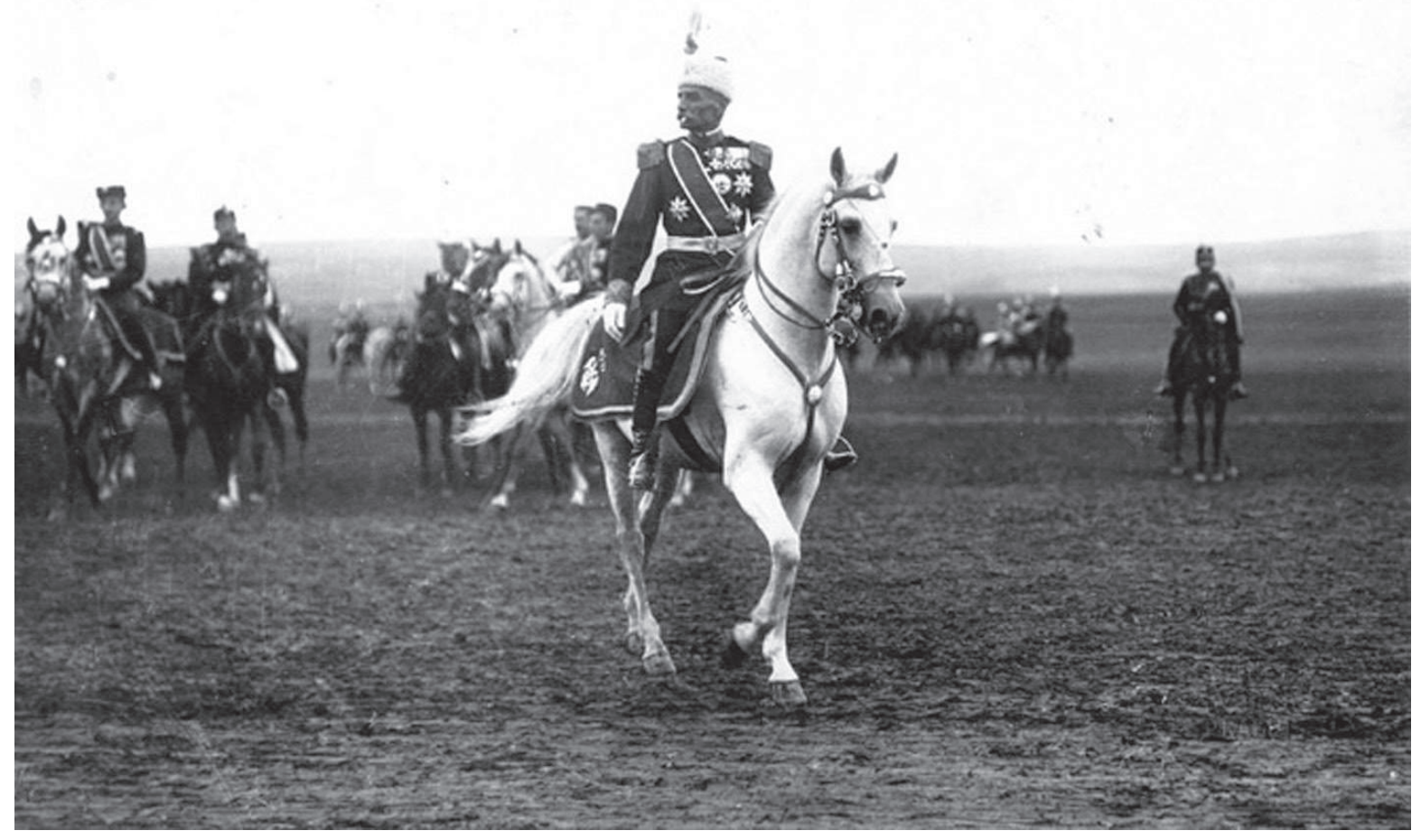

Democracy Rides in to Serbia on a White Horse: King Petar Karađorđević at his coronation in 1904.

Source: Archiv Jugoslavije

The private initiative was appealing to some young Serbs - both from within Serbia and from Habsburg and Ottoman territories who were eager to assist in the important 'national work' of the cetnik committee. ${ }^{7}$ Initially unsupportive of the 'hot heads' in the south, by 1905 the Serbian government was lending official support - both moral and material - to the cetnici. ${ }^{8}$ Expediency sometimes dictated that official Serbia distance itself from the četnici, nevertheless they shared the committee's interest in turning desultory acts of banditry into more concerted anti-imperial guerrilla action. This was the significance of the 1903 coup: it brought the cetnici into closer alignment with official Serbian policy; irredentism in the south had the support of the government.

The aim of Serbian policy in the Ottoman Balkans was both to weaken the empire's grip there and to 'Serbianize' or 'nationalize' the regions as part of their eventual in- corporation into the Serbian state. This meant supporting and promoting the work of četnici who fought against the Ottomans (and against rival Balkan guerrilla groups: especially those from Bulgaria) and disseminating Serbian nationalist propaganda (in churches and schools, for example) so as to strengthen the basis of Serbian national life in Kosovo and Macedonia. It is here that we see the peculiar Janus-face of the Kingdom of Serbia from 1903-1914: both progressive and modernizing and aggressively expansionist and willing to wield violence. On the one hand, the Belgrade government and its supporters were building schools and churches, even theatres - to promote Serbian claims in

7 'Četnička akcija', in Narodna Enciklopedija Srba, Slovenaca, i Hrvata, 4 vols (Zagreb: 1925-1929) vol. I, 427.

8 Aleksa Jovanović 'Četnički pokret u Južnoj Srbiji pod Turcima', in: Aleksa Jovanović ed., Spomenica dvadesetpetogodišnjice oslobođenje južne Srbije (Skopje 1937) 286. See also Vladimir Ilić, 'Učešće srpskih komita u kumanovskoj operaciji 1912. godine', Vojno-istorijski glasnik 43/1 (1992) 198-199. 
Kosovo and Macedonia, on the other hand they were funding and training paramilitary četnici to terrorize non-Serbs and destroy non-Serb culture and heritage. It is no coincidence that this period marked the beginning of the work of the Circle of Serbian Sisters, founded in Belgrade in 1903. The Circle of Serbian Sisters was a nationalist humanitarian society whose activities were focussed primarily on the unredeemed lands of Kosovo and Macedonia. Their humanitarian work appears to be at odds with the violence of the četnici; in fact it was the merely the other side of the Serbian nationalizing mission in the south. Nor is it a co-incidence that a number of četnici were or became schoolteachers, journalists, and parliamentary deputies. They were 'national workers': their portfolios were large and multifaceted.

These nationalizing policies were hardly a Serbian speciality: as Mark Biondich has shown, all Balkan states had in common 'a commitment to the nationalist project, the homogenization of their societies, and the ideology of irredenta.' The 'dynamic of destruction' in the Ottoman Balkans was contested as much between Serbia, Greece, and Bulgaria as it was between those states and the Ottoman Empire. There was certainly much violence against the Muslim population, but there was also much intercommunal violence between the Orthodox Christian populations of the Balkans. In the period 1903-1914 the dynamic reached a peak during the two Balkan wars 1912-1913, whose origins lie in both the relative weakness of the Ottoman Empire in relation to the combined strength of the states of the Balkan Alliance (Serbia, Montenegro, Bulgaria, and Greece) and nationalist rivalries between those Balkan states.

The ethnic cleansing of Muslims in the Balkans in the wake of the Ottoman defeat in 1912 was a result of this dynamic; it was partially a spontaneous by-product of war, 1878 (Oxford 2011).

10 The Other Balkan Wars: A 1913 Carnegie Endowment Inquiry in Retrospect: With a New Introduction and Reflections on the Present Day Conflict by George F. Keenan (Washington DC 1993) 71-78.

11 Ibidem.

12 Leon Trotsky, The Balkan Wars 1912-1913 (London 2008) 161-162.

13 Zoran T. Jovanović, 'Narodno pozorište u Skoplju 1913-1941', in: Vladimir Cvetanović ed., Književnost Stare i Južne Srbije do Drugog svetskog rata (Belgrade 1997). but it was primarily a consequence of a deliberate policy. The Carnegie Endowment Report on the Balkan wars notes tellingly that Serbian, Bulgarian, and Greek authorities did little to prevent atrocities against the Muslim population during and after the First Balkan War. ${ }^{10}$ The victory of the Balkan Alliance meant the destruction and theft of property and systematic mass killing of the Muslim population. ${ }^{11}$ The scale of the violence and the fact that Balkan authorities did little or nothing towards its prevention strongly suggests complicity. On the role of the cetnici, one Serbian soldier, interviewed by Leon Trotsky, claimed these irregulars had committed most of the war's atrocities. The četnici were 'worse than you could possibly imagine. Among them there were intellectuals, men of ideas, nationalist zealots, but these were isolated individuals. The rest were just thugs, robbers, who had joined the army for the sake of loot. ${ }^{12}$

Soon after the First Balkan War, in December 1913, a national theatre opened in Skopje; a seemingly incongruous event in a region recovering from war; it was in fact entirely in line with Serbia's nationalizing programme in the south. The first performance at the new theatre was a re-enactment of the crowning of medieval Serbian king Dušan the Mighty, whose fourteenth century kingdom had been based in Skopje. ${ }^{13}$ Serbian integral nationalists wanted to show that the medieval history of these regions corresponded to the present reality.

The dynamic of destruction is evident once again during the Second Balkan War, which began when Bulgaria attacked its former Balkan allies over competing claims to territories won from the Ottomans in 1912. Serbia's role in the victory over Bulgaria meant yet more territorial aggrandizement. Essentially, the victory meant the realisation of Serbia's maximalist programme in the south. Since the beginning of the First Balkan War Serbia's territory had almost doubled in size and now included most of Kosovo and Macedonia. In the short interbellum between the end of the Second Balkan War and the beginning of the First World War nationalization/Serbianization accelerated. Non-Serbian schools, churches, and cultural institutions were destroyed or closed, non-Serbian language newspapers 
were suppressed, and the Slavic Christian inhabitants - whichever nationality they professed - were declared 'Serbian'. Official Serbia decreed that the regions and their population be assimilated into Serbia proper. And an officially supported settlement programme began in the south, as colonists from Serbia and Montenegro moved into 'newlyliberated' (and newly-vacated) territories. ${ }^{14}$

\section{Austria-Hungary and Serbia 1903-1914}

This new direction in Serbia's foreign policy, culminating in the Balkan wars, was a concern for Austria-Hungary. The Monarchy's Serb population had grown significantly following the occupation of Bosnia in 1878; modern, national, and democratic Serbia was an attractive alternative to imperial rule for some Serbs in Austria-Hungary. Moreover, whilst Aleksandar Obrenović had been amenable to Austria-Hungary and its regional interests, Petar Karađorđević and the Radicals were 'Russophiles' who soon drew the country closer to the Monarchy's imperial rival. Antagonisms between Austria-Hungary and Serbia flared up repeatedly: the two fought a tariff war between 1906-1911 (known as the 'Pig War'); the annexation of Bosnia in 1908 inflamed nationalist circles in Serbia and Bosnia (although it also prompted official Serbia to focus its efforts on the more attainable irredenta in the south); and in 1909 members of the Croat-Serb Coalition in the Croatian Sabor (Assembly) were accused of spying for Serbia in two sensational trials (the 'Zagreb High Treason Trial' and the 'Friedjung Trial'). ${ }^{15}$ The Balkan Wars then raised the stakes significantly. Serbia's spectacular military successes and her territorial aggrandizement in the south persuaded yet more Habsburg South Slavs (not exclusively Serbs) that Serbia could liberate them from imperial rule. A number of them crossed the border in order to volunteer to fight for Serbia. ${ }^{16}$

Serbia's successes also inspired revolutionary South Slav youth in the monarchy to seek 'an unofficial reckoning' with AustriaHungary. ${ }^{17}$ From the beginning of the First Balkan War onwards South Slav youth in the Monarchy attempted a series of attentats on Habsburg functionaries and officials. The assassination of Franz Ferdinand by Gavrilo
Princip and the 'Young Bosnia' movement was the most sensational (and successful) of these attempts. ${ }^{18}$

For many years the question of official Serbian involvement in the Sarajevo assassination preoccupied historians of the First World War and its origins. It now seems certain that no such involvement existed. Clearly integral nationalists in Serbia supported the putative incorporation of Serb-populated Habsburg South Slav lands into an enlarged Serbia; clearly this idea was supported in principle by the Serbian government. But the idea that the First World War started as the 'Third Balkan War' of Serbian national liberation is fanciful; it implies that Serbia could confront Austria-Hungary in Bosnia just as it had confronted the Ottoman Empire in the Balkans. ${ }^{19}$ On this matter there is a visible difference between Serbia's various unredeemed lands during 1903-1914: the links between official Serbia and the četnici are far more pronounced in the south than they are in Bosnia. Moreover, at the time of the Sarajevo attentat the Serbian army was exhausted from fighting two wars, the energies of the Serbian state were absorbed in the 'nationalization' process in the south, and the Radical government was in the middle of a closely-fought election campaign. In the context of the AustroHungarian declaration of war these points hardly matter: the Monarchy had reason to want Serbia's golden age to end. Serbia's successes in the Balkan Wars begged the question of an eventual expansion into Bosnia. Even if such an expansion was not supported in practice by official Serbia in 1914, nationalist groups in Serbia and revolutionary South Slav Youth in the Habsburg lands were ready and willing to force the issue. The assassination of Franz Ferdinand was the casus belli

14 See Milovan Obradović, 'Agrarni odnosi na Kosovu 1918-1941', Jugoslovenski istorijski časopis, 1/4 (1978) 442.

15 See Vladimir Corović, Odnosi između Srbije i Austro-Ugarske u XX veku (Belgrade 1936).

16 Amongst them were the Croatian author Miroslav Krleža and Bosnian Serb schoolboy Gavrilo Princip, the future assassin of Franz Ferdinand. Both were rejected by the Serbian army.

17 The term is Robin Okey's. See Taming Balkan Nationalism: The Habsburg Civilizing Mission in Bosnia 1878-1914 (Oxford 2007) 192-216.

18 On revolutionary youth, see: Mirjana Gross, 'Nacionalne ideje studentske omladine u Hrvatskoj uoči svjetskog rata', Historijski zbornik xxi-xxii (1969); and Josip Horvat, Pobuna omladine 1911-1914 (Zagreb 2006). On the Sarajevo attentat, see: Vladimir Dedijer, Sarajevo 19142 vols. (Belgrade 1978).

19 Joachim Remak, 1914 - 'The Third Balkan War: Origins Reconsidered', The Journal of Modern History 43/3 (September 1971). 
of the Habsburg-Serbian war, but AustriaHungary's underlying aim was to confront and defeat an ascendant enemy.

\section{War and Mass Violence 1914-1918}

The outbreak of war between AustriaHungary and Serbia, then, was the result both of the Serb and South Slav questions within the borders of the Monarchy and the risk of the Kingdom of Serbia staking a claim on Habsburg territories such as Bosnia. Whatever the European or global implications of the First World War, AustriaHungary's war aims in Serbia appear to have been relatively modest: to curtail the nationalist and expansionist currents in Serbia which had been dominant from 1903 onwards. ${ }^{20}$ To a certain extent the Habsburg fear about Serbian expansion in the Monarchy's South Slav lands became a self-fulfilling prophecy. Once attacked, the Serbian government had little to lose by openly stating that they were at war for the 'liberation and unification' from Habsburg rule of all South Slavs. ${ }^{21}$

Austria-Hungary's South Slav problem was thus consolidated: the long-held desire to suppress pro-Serbian and pro-Yugoslav sentiment within its borders was now coupled with the opportunity for a showdown with Serbia itself. Violence and oppression were a function of this consolidated goal. At the beginning of the war, Austria-Hungary suppressed those who were actually or potentially sympathetic to the Serbian cause. Authorities arrested and interned pro-Yugoslav intellectuals such as Oskar Tartaglia, Ante Tresić-Pavičić, and the Bosnian author (and future Nobel-laureate) Ivo Andrić. ${ }^{22}$ Niko Bartulović, a Croat from Dalmatia amongst those interned, claimed that on the

See Jonathan Gumz, The Resurrection and Collapse of Empire in Habsburg Serbia, 1914-1918 (Cambridge 2009) 62-63.

21 See Milorad Ekmečić, Ratni ciljevi Srbije 1914 (Belgrade 1973) 80-112.

22 See: Ivo Tartaglia, Veleizdajnik (Zagreb/Split 1928); and Ivo Andrić 'Prvi dan u splitskoj tamnici: pre deset godina', Vardar (1924).

23 Niko Bartulović, Od revolucionarne omladine do Orjune (Split 1925) 51.

24 Pero Slijepčević, 'Bosna i Hercegovina u svetskom ratu', in: Pero Slijepčević ed., Napor Bosne i Hercegovine za oslobođenje i ujedinjenje (Sarajevo 1929) 226.

25 Vladimir Corović, Crna knjiga patnje Srba Bosne i Hercegovine za vreme svetskog rata 1914-1918 (Belgrade 1989; originally 1920) 139.

26 Slijepčević, Napor Bosne i Hercegovine, 236.

27 R.A. Reiss, Report Upon the Atrocities Committed by the Austro-Hungarian Army during the First Invasion of Serbia (London 1916) 144.

28 See: Andrej Mitrović, Serbia's Great War 1914-1918 (London 2007) 11-23. first day of the war 200 people were arrested in the town of Split alone. ${ }^{23}$ These initial internments developed into a more sophisticated system of camps as the war went on. Austria-Hungary pursued a programme of 'denationalization' that concentrated on the Serbian population, but which also targeted pro-Yugoslav South Slavs. According to one estimate, 3323 people from Bosnia were interned during the war at the Arad camp in Hungary, of whom 553 did not survive. ${ }^{24}$ Municipal, military, and judiciary authorities were purged of Serbian or pro-Yugoslav elements. ${ }^{25}$ The largest trial of Serbs took place in Banja Luka from $\mathrm{N}$ ovember 1915 until April 1916, when 156 Serbian intellectuals and political and ecclesiastical leaders were accused of spying for Serbia. Sixteen of the accused were sentenced to death and eight-six to hard labour. ${ }^{26}$ In occupied Serbia itself, violence committed by the AustroHungarian army was related in part to fears that četnici had secreted themselves amongst the civilian population. Swiss criminologist Rudolph Archibald Reiss, who gathered information on Austro-Hungarian atrocities against Serbs during September, October, and November 1914, saw a design in this violence. According to Reiss, the extent of violence - which included hangings, burning of property, and pillage - meant that it was impossible to look upon the atrocities that have been committed as the acts of a few apaches'; the violence was in fact 'systematic., ${ }^{27}$

We must reject the idea of a pathological hatred of Serbia on the part of AustriaHungary as the root cause of violence during 1914-1918, or the idea that violence was simply a form of collective punishment on Serbia for killing Franz Ferdinand. This element was certainly present: spontaneous anti-Serb demonstrations - even pogroms - took place in towns across Croatia and Bosnia in the days after the attentat. ${ }^{28}$ However, the duration and extent of the violence, its co-ordination, and its official sanction confirm its intent: Austria-Hungary wanted to take Serbia back to its pre-1903, pre-coup self. The occupation authorities even raised a monument to Aleksandar Obrenović and Draga Mašin in Belgrade during the war, a reminder of a more acceptable period of Habsburg-Serb relations. 


\section{Croat Support for War against Serbia: The Frankists}

There is another important dimension to the violence of 1914-1918: the Habsburg-Serb war was to an extent also an inter-ethnic conflict between Habsburg South Slavs and Serbia. This dimension was significant for the future South Slav state. We have seen that Austria-Hungary was greatly concerned, before and during the war, with South Slavs who supported Serbia against the Monarchy. In fact, there were also many South Slavs who were loyal to the Habsburgs. No group was louder in its support of Austria-Hungary's war and in its attacks on Serbia and Serbs than the Croatian Pure Party of Right known as the 'Frankists - a Croatian nationalist opposition faction in the Sabor whose anti-Serbianism sat well with Habsburg war aims in Serbia. ${ }^{29}$ It was the Frankists' hope that their loyalty to the Habsburgs would be rewarded in the post-war period with a reorganization of the Monarchy which raised South Slavs (that is to say, Croats) to the same level as Hungarians and Germans, thus replacing 'dualism' with 'trialism., ${ }^{30}$ To this end, they shared the Habsburgs' desire to reverse nationalist trends amongst the Serbs.

The Frankists were in opposition in the Sabor during the war, divided internally and defeated in the 1913 elections by the CroatSerb Coalition. They were a minority voice, but their loyalty to the Habsburgs meant they were close to ruling circles. They were a Habsburg elite and their support of AustriaHungary's war meant they were favoured by another of the Monarchy's elites: Habsburg army officers of Croat descent. Like the Frankists, many such officers did not see a contradiction in fighting for both Habsburg and Croat interests during the war: the common enemy was Serbian nationalism and the reward was increased autonomy within the Monarchy (it must be remembered that until a very late stage in the war most people in and out of Austria-Hungary expected the Monarchy to survive in some form or other). Examples of higher-ranking soldiers who supported the Monarchy abound: perhaps most notable was Stjepan Sarkotić, military governor general of Bosnia and Dalmatia for most of the war. Sarkotić was a supporter of the 'trialist' solution, and it was he who ar- ranged the 'Banja Luka Trials ' of 1916-1917 with the aim of decapitating the Serbian national elite in Bosnia. Johann Salis-Sewis, the Croat general and governor of occupied Serbia, shared his views. Salis-Sewis also had a radical solution to the Serbian problem: the incorporation of Serbia into the Monarchy and the continued suppression of Serbian national life. As he vividly put it, 'it is better that an enemy is in my room where I hold a pistol than outside my door with a pistol in his hand.' ${ }^{31}$

For their part, it seems that the Frankists hoped that something definite would come from their links with ruling Habsburg circles and their proximity to the Habsburg military. Frankist leaders had previously raised the idea of a 'Military Commissariat' of Habsburg generals taking control in the Croat lands. In the middle of 1918 , as the war reached a critical stage for Austria-Hungary, police in Zagreb found documents in which leading Frankists called for a suspension of the Sabor and the introduction of military rule in Croatia. ${ }^{32}$ The Frankists hoped that an Austro-Hungarian general would be able to prevent 'Serbian sabotage' in the region; they also preferred the idea of pro-Habsburg military rule to the Croat-Serb Coalition's civilian assembly. The plan for a military commissariat was not realized - and was probably never likely to be realized - nevertheless, it demonstrates the close relationship between the Frankists and Habsburg military circles before and during the war.

Austria-Hungary's defeat in 1918 was also the defeat of the Frankists and their supporters in the Habsburg officer corps. For many Frankists, the Allied and Serbian victory confirmed their worst fears: a supercharged Serbian nationalism had defeated Austria-Hungary and now dominated the other South Slav nationalities in Yugoslavia. In fact, their defeat was two-fold: not only

29 Damir Agičić, 'Civil Croatia on the Eve of the First World War (The Echo of the Assassination and Ultimatum)', Povijesni prilozi Institut suvremenu povijest 14 (1995) 305.

30 For a useful English-language account of the Frankists during 1914-1918, see Stjepan Matković, 'Members of the Party of Right and the Idea of the Croat State during the First World War', Review of Croatian History 4 (2008).

31 Petar Opačić, 'Politika genocida austrougarske protiv Srba u prvom svetskom ratu', Vojnoistorijski glasnik 1/4 (1994) 66-67.

32 I am in debt to Stjepan Matković for information on this episode. See also: Matković, 'Members of the Party of Right and the Idea of the Croat State during the First World War', 32-33. 
had the Franksts been intimately connected to the defunct empire - a fatal association in Serb-dominated Yugoslavia - they were also eclipsed in interwar Croatia's politics by the mass popularity of Stjepan Radićs peasant party. Frankist support was restricted to a certain section of the Zagreb bourgeoisie or else scattered in emigration, where former officers such as Stjepan Sarkotić organized small groups of anti-Yugoslav émigrés and exiles.

We cannot, however, dismiss the Frankists on account of their small size and marginality in the 1920s. In the 1930s, a significant number of Frankists and exHabsburg officers graduated to the Ustasha Croatian Revolutionary Organization (The Ustashe), the paramilitary-terrorist group which, whilst in government in the Nazibacked Independent State of Croatia (NDH, 1941-1945), was responsible for the genocide of Jews, Serbs, and Roma. The transformation occurred after the promulgation of King Aleksandar's dictatorship in 1929. The founders of the Ustashe, leading Frankists Ante Pavelić and Gustav Perčec (the latter a former Habsburg officer), decided that the dictatorship called for a more radical kind of resistance. Pavelić and Perčec recruited likeminded Croats (including a number of exHabsburg officers) to their cause: the violent overthrow of Yugoslavia and the realization of Croatian autonomy. Ustasha ideology and tactics were not entirely sui generis, however: to a great extent they were rooted in the Frankist movement and its programme of integral nationalism.

\section{After 1918: (Serbian) Civilization and its Discontents}

If the Frankists were the great losers of the First World War, Serbian integral nationalists were the winners. The creation of Yugoslavia in 1918 owed much to the Allied victory and Serbia's role in that victory. That debt was evident in the set-up of the new state: the political, constitutional, and economic frameworks of Yugoslavia derived in large

33 See, for example: Sabrina Ramet, The Three Yugoslavias: State-Building and Legitimation, 1918-2005 (Indiana 2006) 37-39.

34 The classic work on the formation of Yugoslavia after 1918 and the violence which attended it is Ivo Banac, The National Question in Yugoslavia: Origins, History, and Politics (Ithaca 1984). part from those of the pre-war Kingdom of Serbia. In addition to this, the pre-war Serbian army and gendarmerie supplied the model (and usually the personnel) for the Yugoslav army and gendarmerie. From these facts many historians of the interwar kingdom have argued that Serbs considered the new state merely an enlarged Serbia in which the non-Serb lands were their spoils of war. ${ }^{33}$ In fact, most Serbs were not willing to have their national identity subsumed within a Yugoslav identity and did not consider lands such as Croatia, Slovenia, and Dalmatia part of an 'enlarged Serbia'. This is not to say that these lands were spared from exploitation and suppression by the Belgrade regime after $1918{ }^{34}$ However, full-scale assimilation, or Serbianization, after 1918 was restricted to those areas that Serbian integral nationalists had coveted before the war: Macedonia, Kosovo, and the formerly Habsburg regions of 'Serbian' Bosnia. The Serbian national project of 1903-1914 recommenced after 1918 , but it was no longer inhibited by the existence of great empires. A look at the history of these regions in the 1920s shows the continuities between pre-war and post-war Serbian integral nationalism. The Yugoslav government did not acknowledge the separate character or status of the 'southern regions': Macedonia was 'South Serbia' and Kosovo was 'Old Serbia', or, once again, the 'classical south'. The government categorized all Slavs living there as Serbs, and official policy called for their 'assimilation'. Only Serbian schools, churches, and cultural organizations were allowed to operate in the region; the Bulgarian language was removed from public and official spheres.

Once again, development and modernization were largely inseparable from nationalization and Serbianization. The classical south - along with Vojvodina in the north of Yugoslavia - was central to the post-1918 programme of land reform and internal colonization. Veterans of the Serbian army and their families were often the beneficiaries of this programme; they received plots of land throughout Macedonia and Kosovo. The government was open about the nationalizing aims of these policies: they hoped to create (Serbian) ethnic homogeneity in areas depopulated by war; they also hoped to raise the 'national consciousness' of areas that were 


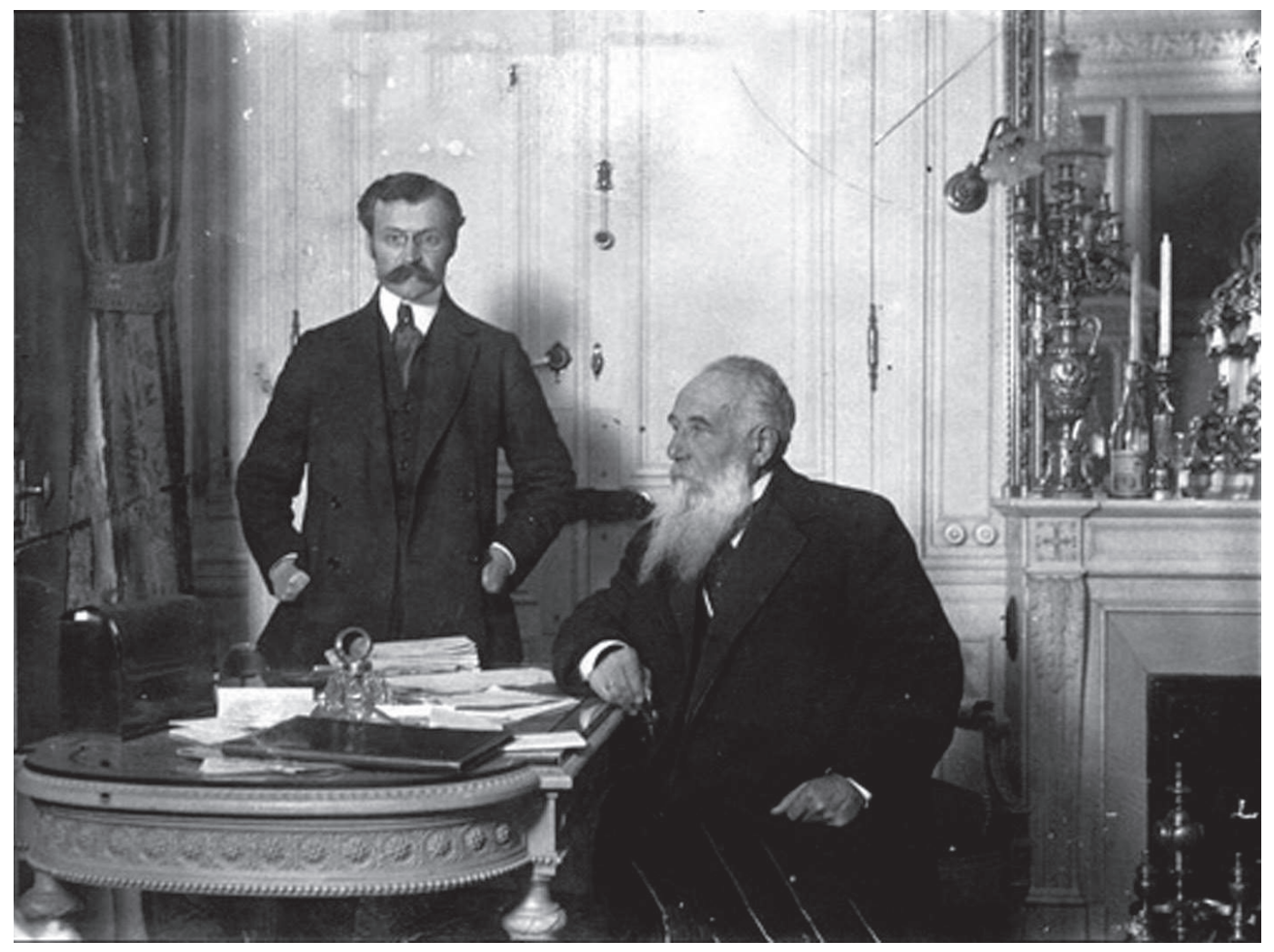

The Architect of Great Serbia: Radical Party leader and wartime prime minister Nikola Pašić (right), with the diplomat Jovan Jovanović ‘Pižon.

Source: Archiv Jugoslavije

considered integrally Serbian (Macedonia and Kosovo) - or at least Yugoslav (Vojvodina)..$^{35}$ For former soldiers and četnici who became colonists, moving to the south was akin to taking part in a (Serbian) civilizing mission. Representative of this trend was Stevan Simić, a četnik since before the war, a former student of noted Serbian geographer Jovan Cvijić, and a schoolteacher and journalist in post-war Macedonia. He wrote extensively and critically on the political corruption and anti-Serbian banditry in the classical south in the 1920s. Indeed, a number of journals appeared whose aim was to promote the region's Serbian character and the important work of the colonists; their titles suggest their nationalist content: Southern View, South Serbia, Serbian Kosovo. The contributors to these journals, men like Simić, highlighted the need for a systematic and sustained programme of colonization in the south to go hand in hand with the building of schools, hospitals, and other modern infrastructure, and more generally to raise the level of culture in the regions. As one proponent of colonization as nationalization put it at a lecture in Mitrovica, colonists from 'more cultured parts' could show southerners that 'love towards progress and work is a greater ideal than the traditional and nasty practice of bloody revenge', i.e., modernity and modernization were ideals to strive for in the still underdeveloped classical south. ${ }^{36} \mathrm{It}$ was an ideal also held by the Circle of Serbian Sisters, whose members were once again active in the region after a wartime hiatus. Just as before the war, the humanitarian and charitable work of the women focussed in large part on Kosovo and Macedonia; because those were the poorest regions of Yugoslavia, but also because the work of nationalization needed to continue here.

In the north, too, colonization was linked to nationalization, although of a different

35 Milivoje Erić, Agrarna reforma u Jugoslaviji 1918-1941 (Sarajevo 1958) 296297.

36 Srpsko Kosovo, 15 July 1921. 
sort. In Vojvodina - formerly a Habsburg region - the need for modernization was less urgent than in the south, but the presence of a large population of ethnic Hungarians and Germans meant there was a need to reinforce the 'national element' here. As one national worker put it in a publication of 1931, 'Bačka and Banat [districts in Vojvodina] are the least national of all our regions - even less so than South Serbia, since there the population is three-fifths Slav, here is it just twofifths.' The aim of nationalization in these parts was to create a majority population of 'Yugoslavs'. ${ }^{37}$ Note the author's terminology, 'Yugoslavs', not 'Serbs'; unlike the southern regions, Vojvodina was considered a Yugoslav rather than a Serbian territory. It is not accidental, in this respect, that many colonists in the north were 'Yugoslav volunteers', i.e., Habsburg South Slavs who had fought in the Serbian army during the war. The intellectuals and national workers amongst the volunteers considered themselves first and foremost Yugoslavs (rather than Serbs, Croats, or Slovenes); many of them received parcels of land in Vojvodina. In a memorandum issued publicly to the government in 1923 the Volunteer Union, a veterans' organization, called upon the government to settle former volunteers in Vojvodina to keep 'separatists' and 'anational elements' in check. ${ }^{38}$

Violence attended this nationalizing project, as it had before the war. This was especially true in Macedonia and Kosovo, where the Yugoslav authorities met significant resistance from Albanian 'Kaçak' guerrillas and the Internal Macedonian Revolutionary Organization (VMRO). Settlers were both perpetrators and victims of violence here during the interwar period. On the one hand, former četnici established paramilitary groups such as the 'Association Against Bulgarian Bandits' - based in Štip - ostensibly for self-defence, its members often terrorized the non-Serb population. On the other hand, Kaçaks and the VMRO killed, kidnapped, and terrorized civilian settlers and the Serbian population with the aim of discouraging further settlement in the re-

Vladan Jojkić, Nacionalizacija Bačke i Banata: etno-politička studija (Novi Sad 1931) 5.

38 Memorandum Savez dobrovoljaca (Belgrade 1923) 15

39 See his report in full: Reiss, The Comitadji Question in Southern Serbia (London 1924). gion. Rudolf Archibald Reiss estimated that by 1923 as many as 300 Serbs (excluding soldiers and gendarmes) had been killed in guerrilla attacks in Macedonia and Kosovo. ${ }^{39}$

The creation of Yugoslavia in 1918 was not a tabula rasa for Serbian integral nationalism; neither were Yugoslav and Serbian national projects co-extensive in the interwar period. The colonization and land reform policies and the support for them from former soldiers and cetnici in the south show that the programme of Serbian integral nationalism of 1903-1914 was revived after 1918. In fact, the programme accelerated after the end of the war, since it was no longer encumbered by great empires and could be carried out within the borders of a sovereign state. The relationship between the Serbian and Yugoslav nation-building projects in the 1920 s was not one of identity, as the differences between policies in the south and in Vojvodina demonstrate, it was rather a relationship of compatibility; in the first decade after the formation of Yugoslavia, this compatibility held.

\section{The Failures of Yugoslavia and the Harde- ning of Serbian Nationalism}

Given these favourable conditions, it is perhaps surprising that the nationalizing project of the interwar period was unsuccessful. The lack of security in Kosovo and Macedonia led to many colonists moving away from the regions; many more were discouraged from moving south in the first place. The regions remained the least developed in Yugoslavia throughout the interwar period. This problem was actually exacerbated by the official policy of land reform, since it favoured former soldiers and četnici who were either not qualified to till the land, or else were not provided with the appropriate equipment to do so by the government. The concerns voiced in nationalist journals from Kosovo and Macedonia became increasingly impatient with the lack of progress made towards nationalizing the regions. The contributors to these journals, many of them former četnici, complained that colonization and land reform programmes were 'unsystematic', that corruption was rife - especially in politics, and that a national culture in the south was conspicuous only in its absence. Adam Pribićević, a prominent journalist and settler (and brother of the lea- 
der of the Independent Democratic Party Svetozar Pribićević), wrote of the extreme hardships that colonists faced in the south in his memoirs From a Gentleman to a Peasant. Pribićevičs book catalogued the failures of the Serbian civilizing mission in the south: constant danger of Kaçak raids, the unsystematic approach to settlement taken by the government, the corruption of civil servants and politicians. ${ }^{40}$ Those shortcomings were also reflected in the most successful novel about the 'Serbian South' in the interwar period: Anđeljko Krstičs Trajan (1932). The novel's protagonist grows up in the Ottoman Balkans and goes to war with the Serbian army for the 'liberation and unification' of the southern regions. After 1918 he returns to find his home just as benighted in Yugoslavia as it had been under the Ottomans. He eventually succumbs to the hardships of life in the post-war 'classical south', dying of tuberculosis. The author of Trajan had captured the sense of failure and disappointment that, for many Serbian nationalists, marked the recent history of the classical south.

It was not the case, however, that the classical south was merely a black mark on an otherwise good report: Yugoslavia's failures were not restricted to the 'Serbian' regions of Kosovo and Macedonia. Throughout the 1920s the country's politics had been in a state of permanent crisis. In 1929 King Aleksandar suspended parliament indefinitely and promulgated a personal dictatorship that lasted until his death in 1934. Concerned by the lack of progress the country had made in its first ten years, Aleksandar hoped to integrate Yugoslavia 'from above' by forcing a supranational identity on his subjects that would replace existing 'tribal' (that is: national) identities. Despite the best efforts of the king and his supporters, the period of royal dictatorship was also a failure: South Slavs were not unified by Aleksandar's 'topdown' Yugoslavism, they were pushed farther apart. The dictatorship ended abruptly when Aleksandar was assassinated in October 1934 (by Croatian and Macedonian extremists, see below), but it had been failing for some time before that.

If Aleksandar had looked closely at the passions that drove the Serbian national project in Macedonia and Kosovo, he might have understood the task he faced. As already noted, Serbs, like other South Slavs, were not willing to relinquish their national identity in Yugoslavia. The authority of the king and the Karađorđević dynasty muted opposition to the dictatorship in Serbia; with Aleksandar gone, Serbian criticism of Yugoslavia became louder. After 1934, the relationship between Yugoslavia and Serbia seemed to be less and less one of compatibility. Failures in the south and divisions within Serbian politics gave many Serbian nationalists cause for reflection: they wondered what had happened to the unity and the sense of purpose the Serbs had in the pre-war kingdom from 1903-1914 (and it was this backward gaze that contributed greatly to the subsequent image of this period as a 'golden age'). Preoccupied with the notion that Serbs were not united in Yugoslavia, a group of Serbian intellectuals formed the Serbian Cultural Club in 1937: a 'non-political' and 'non-party' organization whose aim was to promote Serbian values and interests in Yugoslavia. ${ }^{41}$ The club and its supporters saw themselves as the true heirs of the Serbian nation since 1903. As the editor of the Club's journal, Dragiša Vasić - a veteran of the First World War - put it, 'For once a Serbian voice should be heard [the club's journal was called The Serbian Voice], free from all foreign theories and party biases, so that a strong Serbdom can permeate Yugoslavia with its esprit de corps and stand as a testament for future generations. ${ }^{42}$ The Serbian Cultural Club, true to its roots, was also Janus-faced: non-political but consistently in opposition to the Yugoslav regime, its members professed loyalty to both Yugoslavia and Serbia but increasingly placed one in opposition to the other. And whilst ostensibly modern and progressive, its members sought extreme solutions. The two sides are present in Vaso Čubrilovič's notorious memorandum to the Serbian government in 1937, having to do with "The Explusion of Arnauts [Albanians]'. Čubrilović advised that '[T] he only way and means to cope with them [Albanians] is the brute force of an organized

40 See: Adam Pribićević, Od Gospodina do Seljaka (Zagreb 1996).

41 For a recent English-language piece on the club's activities see: Dejan Djokic, 'National Mobilization in the 1930s: The Emergence of the "Serb question" in the Kingdom of Yugoslavia', in: Dejan Djokić and James KerLindsay eds., New Perspectives on Yugoslavia: Key Issues and Controversies (London 2011).

42 Srpski Glas, 16 November 1939. 


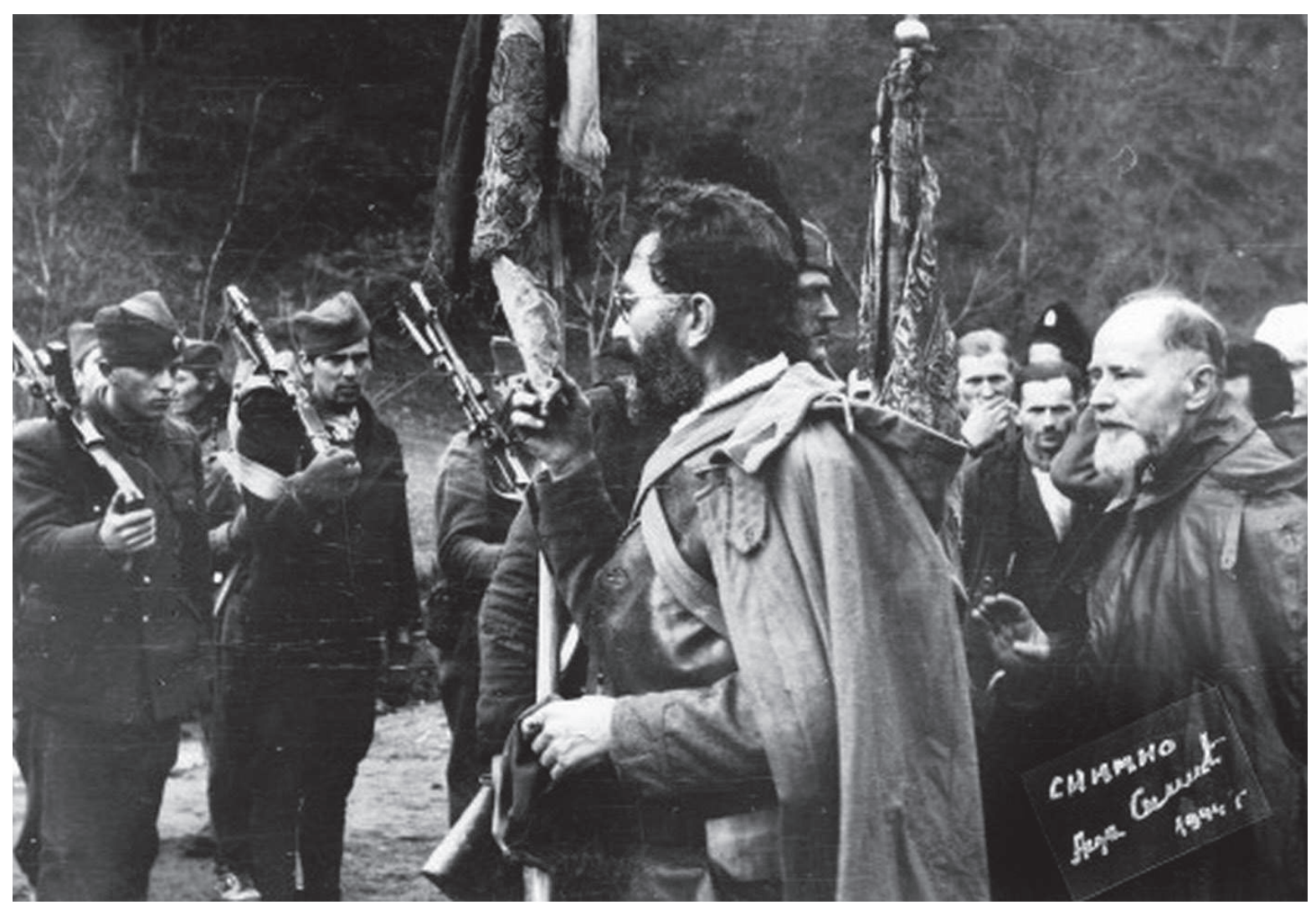

The Soldier and his Ideologue: Dragaljub ‘Draža’ Mihailovic (centre) and Dragiša Vasić (far right) at the Chetnik congress in Ba, Serbia, January 1944.

Source: Archiv Jugoslavije

state'. He went on to suggest various legal harassments to which the Albanians could be subjected, 'fines, imprisonments, the ruthless application of all police dispositions', failing these, "[T]here remains one more means, which Serbia employed with great practical effect after 1878, that is by burning down Albanian villages and city quarters.' ${ }^{43}$ The Yugoslav government did not adopt any of Čubrilović's suggestions, the country's leaders were not willing to resort to mass violence in times of peace. Čubrilović's memorandum is indicative of a hardening of the Serbian national programme in the 1930s. It was this hardened programme that the Yugoslav Army in the Homeland (the Chetniks) put into effect during 1941-1945.

\section{Mass Violence during 1941-1945 and its Aftermath}

Was the violence of 1941-1945 a reprisal of 1914-1918? Not exactly, but there are some important associations. The Ustasha programme, for example, owed much to the attitudes and ideas of conservative supporters of Austria-Hungary before 1918: the Frankists and ex-Habsburg officers. The Ustashe often claimed it was the violence and suppression of the Alexandrine dictatorship of the 1930s which, in turn, drove them to violence and terrorism. In fact, their programme was as much anti-Serb as it was anti-Yugoslav. Like the Habsburgs before them, the Ustashe sought to solve the 'Serbian problem' on the territory they controlled. National Socialism inspired Ustasha genocide against Balkan Jews and Roma, but the genocide of Serbs in the Independent State of Croatia during the Second World War was entirely of their own design. There were structural similarities to the Habsburg programme of Serbian 
'denationalization' during the First World War (camps, suppression of cultural life); but the Ustasha programme was far more radical and therefore far more violent. The complete removal of Serbs from the Independent State of Croatia appears to have been the goal of Ustasha policy during 1941-1945, although conversion to Catholicism, either forced of voluntary, was also sanctioned. In both the First and the Second World War, this vision of an enlarged Croatia cleansed of Serbs and Serbian nationalism was the preserve of a minority: the Frankists, then the Ustashe. Both groups owed their influence to external powers rather than popular support.

The Yugoslav Army in the Homeland the Chetniks - was to a certain extent the heir of the Serbian nationalist project that began in 1903. The ideology and intentions of this group are harder to place than those of the Ustashe. Unlike the Ustashe, the Chetniks did not have control of a state; they left far less of a paper trail of directives and orders for historians to follow. Dragoljub 'Draže' Mihailović, the nominal leader of the Chetniks, did not have complete control over his forces and, initially at least, he wanted to keep them out of politics in order to focus on military matters. He was unsuccessful in this respect, and the politically inexperienced Mihailović allowed Chetnik ideology to become defined by leading members of the Serbian Cultural Club such as Dragiša Vasić and Stevan Moljević. Just as they had during the interwar period, these intellectuals mulled over the proper relations between Serbia and Yugoslavia; once again they decided in favour of the former. The Chetnik programme closely resembled the Serbian maximalist programme of the past; it was true to the spirit of Serbian nationalism after $1903 .{ }^{44}$ The genocide against non-Serbs committed by the Chetniks during the Second World War was inspired by the pre-war attempts to Serbianize and nationalize areas such as Kosovo and Macedonia. Now the programme was shifted to Serb-populated areas of Bosnia.

The Chetniks had almost no support outside of Serb populated lands, and the Ustashe, eventually, lacked support anywhere, with the possible exceptions of larger Croatian cities such as Zagreb and Karlovac. Both were narrowly nationalist movements operating in nationally-mixed areas, factors which contributed to a) the use of mass violence by the Ustashe and the Chetniks to create ethnically homogenous areas, and b) their lack of success in Yugoslavia. The socialist Partisans were the only truly Yugoslav resistance force during 1941-1945, and they drew the support of many non-Communists throughout the country. This fact has led one eminent historian of the civil war in Yugoslavia to ask whether, by 1945 'for many, Yugoslavia was again, perhaps, not a bad idea, and one that was certainly better than the alternatives experienced during that period?' 45 Perhaps, or perhaps the Partisans were merely the best of a bad bunch, the only combatant in the civil war whose violence was contextual rather than programmatic.

If the Partisans supported a return to Yugoslavia against the nationalist projects of the Ustashe and the Chetniks, their design for the new state was truly revolutionary. Unlike the centralized interwar kingdom, the second Yugoslavia was a federation of socialist republics. Macedonia was no longer an integral part of Serbia, but a republic in its own right, as was Bosnia: separate from both Croatia and Serbia. Kosovo was more problematic. The socialists incorporated Kosovo into Serbia, but not on the same terms as in the interwar kingdom: it was made an 'autonomous region' within the Serbian socialist republic. We can see, then, the important ways in which the socialists rejected the politics of the interwar period. Yugoslavia was reborn, but as a very different entity. Much was made by Serbian nationalists in the 1980s about the socialists' reluctance to allow Serbian and Montenegrin colonists from the interwar period to return to Kosovo after 1945 (they had been expelled during 1941-1945). In fact, the colonization programme, as we have seen, was already in retreat at the end of the 1920s, the number of settlers remaining in 1941 was small, and by 1945 many of them did not want to return to the southern regions at all. ${ }^{46}$ The inability of Serbian in-

44 See: Jozo Tomasevich, War and Revolution in Yugoslavia: The Chetniks (Stanford 1975) 166-167. See also the discussion of 'Chetnik ideology' in: Tomislav Dulić, Utopias of Nation: Local Mass Killing in Bosnia and Herzegovina, 1941-1942 (Uppsala 2005) 109-114.

45 Stevan K. Pavlowitch, 'Sabrina P. Ramet, The Three Yugoslavias: State Building and Legitimation 1918-2005', book review, in: Journal of Southern Europe and the Balkans 10/1 (April 2008) 129.

46 See: Tim Judah, Kosovo: A Short History (London 1998) 317-318. 


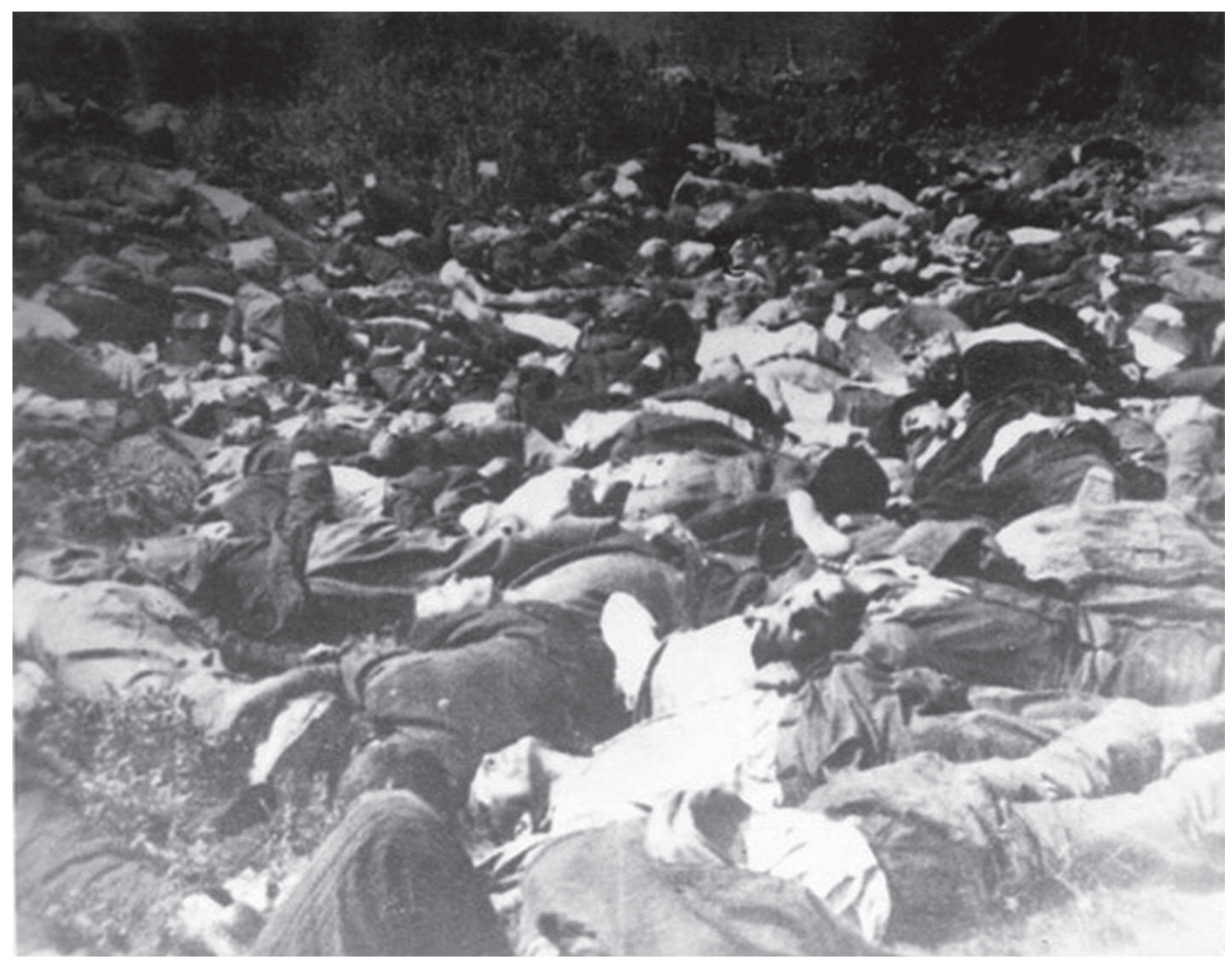

Ustasha Violence: Mass shooting of Serbs by Ustashas in Bosanka Dubica 1941.

Source: Archiv Jugoslavije

tegral nationalists to Serbianize Macedonia and Kosovo during the interwar period and the desire of the socialists to curb the kind of Serbian nationalism which had been so damaging from 1903-1945 contributed to the decision to separate the regions from Serbia. This separation incubated autonomous sentiment from 1945 onwards and contributed to their eventually breaking away from Serbia and Yugoslavia in the last decade of the twentieth century. In the case of Kosovo, violence in the region at the end of the twentieth century shows that for many Serbs, the nationalist attitudes prevalent during 1903-1945 were still relevant.

\section{Conclusion}

Interwar Yugoslavia cannot be described as a peaceable kingdom, but it did not experience mass violence during 1918-1941.
However, its short existence began and ended in extreme violence, and it was stalked throughout the interwar period by Serbian and Croatian integral nationalisms. Serbian integral nationalists were for a short time in accord with Yugoslav state-builders, but in 1930s they were increasingly separated from the Belgrade regime. One historian has described the contortions and accommodations of the high politics of interwar Yugoslavia as a quest for the 'elusive compromise' between all parties that would make the state viable. ${ }^{47}$ Rather than trying to follow these twists and turns, we could look instead at the continuity of Serbian integral nationalism from 19031945 as a way of understanding the shortcomings of the state and the causes of mass violence in the Balkans. We could also look at its opponents amongst the South Slavs, the Frankists and their successors, the Ustashe. They were the ghosts at the Yugoslav banquet, a trace of Austro-Hungarian policies in the Balkans, insignificant and ineffectual without external backing. When this bac- 
king came during the Second World War, the revived plan for denationalizing Serbia was more radical and violent than it had been during the First World War. The success of the Partisans was at the same time, of course, the failure of the Chetniks and the Ustashe, but it was also the failure of programmes of integral nationalism whose roots lay far deeper in the region's history.

John Paul Newman is Lecturer in Modern European History at the National University of Ireland, Maynooth. He is researching the social and cultural history of Yugoslavia and the Balkan region, and is preparing a monograph about the wartime generation in Yugoslavia, provisionally titled Embattled Kingdom: the South Slav Wartime Generation and the Breaking of Yugoslavia 1918-1945. 